\title{
Performance of Nutrients and Plant Growth Regulators on Growth and Quality attributes of Onion (Allium cepa $\mathrm{L}$.)
}

\author{
Priynka Kumari Jat ${ }^{1 *}$, S.K. Khandelwal ${ }^{2}$ and J.S. Maharia ${ }^{2}$ \\ ${ }^{1}$ Rajasthan Agricultural Research Institute, Durgapura Jaipur, India \\ ${ }^{2}$ S.K.N. College of Agriculture, S.K.N. Agriculture University, \\ Jaipur, Rajasthan-302018, India \\ *Corresponding author
}

\begin{tabular}{l} 
Ke y w o r d s \\
$\begin{array}{l}\text { Growth, Bulb yield, } \\
\text { Onion, Pant growth } \\
\text { regulators, } \\
\text { Nutrients }\end{array}$ \\
\hline Article Info \\
$\begin{array}{l}\text { Accepted: } \\
24 \text { September } 2020 \\
\text { Available Online: } \\
10 \text { October } 2020\end{array}$ \\
\hline
\end{tabular}

\section{A B S T R A C T}

The field experiment was conducted to study the "Effect of Nutrients and Plant Growth Regulators on Growth, Yield, Quality and Storage Life of Onion (Allium cepa L.)" in loamy sand soils of the Research Farm, Rajasthan Agricultural Research Institute Durgapura (Jaipur, Rajasthan) during rabi season 2016-17 and 2017-18. The experiment consisted four nutrient combination (NP, NPK, NPKS and NPKSB) and four treatment were nutrient and plant growth regulators (Control, $\mathrm{CaCl}_{2} @ 0.5 \%$, ethephon@3000 ppm and mepiquat chloride@750 ppm) under three curing methods (Field curing, curing under 60\% shade and curing under poly tunnel) thereby making forty-eight treatment combinations tested in factorial randomized block design with three replications. Results indicated that application of NPKSB and mepiquat chloride@750 ppm significantly higher growth and quality attributes of onion over other treatments. The result also indicated that field curing significantly increased total soluble solids over poly tunnel curing and $60 \%$ shade net curing.

\section{Introduction}

Onion (Allium cepa L.) is one of the most important commercial vegetable crops cultivated extensively in India and it belongs to family Alliaceae. Onion is an indispensable item in every kitchen as vegetable and condiment, therefore commands, an extensive internal market. Onion is liked for its flavour and pungency which is due to the presence of a volatile oil 'allyl propyl disulphide'- organic compound rich in sulphur. Onion is used in pharmaceutical preparations due to its medicinal values. Onion is also known to cure heart diseases as it checks the deposition of cholesterol in blood vessels. 
Availability of nitrogen is important for growing plants as it is major indispensable constituent of protein and nucleic acid. Being a part of plant hormones, it is involved in regulating plant growth and developmental processes. Similarly, Phosphorus is indispensable constituent of nucleic acids, phospholipids and several enzymes. It is also needed for the transfer of energy within the plant system and is involved in its various metabolic activities (Yalwalker et al., 1962). Potassium imparts vigour and disease resistance to the plant and plays an important role in crop productivity. The essential role of $\mathrm{K}$ in numerous physiological and biochemical processes in the plants including photosynthesis, enhancing the translocation of assimilates, protein synthesis, maintenance of water balance, and promoting enzyme activities are well established (Marschner, 2012).

Likewise, sulphur is an essential constituent of certain amino acids namely cysteine and methionine and involved in synthesis of proteins and sulphur bearing vitamins like biotine, thiamine and some co-enzymes. It is a constituent of "Allyl propyl disulphide" which imparts the pungency in onion. Boron deficiency affects reproductive growth more than vegetative growth. Calcium is a key component of cells maintaining structure of cell walls and stabilizing cell membranes. Calcium is essential for translocation of carbohydrates and nutrients. Accumulation of carbohydrates in leaves under calcium stress decrease carbohydrate content of stems and roots, which impairs normal root function. Mepiquat chloride induce extension in storage life of onion might be due to anti-gibberellin action, which might have facilitated the maintenance of quality of bulbs in storage with respect to inhibition of sprouting, leading to reduction of moisture and physiological loss in weight (Rahman and Isenberg, 1974). Ethrel played an important and pivotal role in increasing the bulb yield as it accelerated bulb enlargement and the photoperiodic phenomenon that induced synthesis, translocation and accumulation of assimilates resulting in increasing the bulb size. Curing can be defined as removing the excess moisture from the outer layers of the bulb prior to storage. Curing decreases the incidence of neck rot, reduces water loss during storage, prevents microbial infection, and is desirable for development of good scale colour, thereby preserving the main edible tissue in a fresh state.

\section{Materials and Methods}

The experiment was conducted at the Research Farm, Rajasthan Agricultural Research Institute, Durgapura, Jaipur (Rajasthan). The region falls under AgroClimatic Zone III- A (Semi-Arid Eastern Plain). Durgapura is situated at $26.5^{\circ}$ North latitude, $75.47^{\circ}$ East longitude and an altitude of 390 meters above Mean Sea Level in Jaipur district of Rajasthan. The initial soil fertility status of experimental plot was well drained clay loam with $\mathrm{pH} 8.00$ and EC 0.80 $\mathrm{ds} \mathrm{m}^{-1}$. The available $\mathrm{N}, \mathrm{P}, \mathrm{K}$ and $\mathrm{S}$ content of the soil were $248.11,11.14,168.41$ and 13.10 $\mathrm{kg} / \mathrm{ha}$, respectively. The experiment was laid out in Factorial Randomized Block Design with three replications and consisting of Forty-eight treatments combination. The onion cultivar RO-59 was sown in nursery beds during November and transplanted in January with space of $15 \times 10 \mathrm{~cm}$ between rows and plants, respectively. All nutrients like NP@100:50 kg/ha, NPK @100:50:150 kg/ha, NPKS@100:50:150:45 kg/ha and NPKSB@ 100:50:150:45:1kg/ha and nutrients and plant growth regulators viz like control, $\mathrm{CaCl}_{2} @ 0.5 \%$, ethephon@3000 ppm and mepiquat chloride@750 ppm and curing methods viz field curing, curing under $60 \%$ shade and poly tunnel curing. Fertilizers were applied as per treatment through Urea, DAP 
and MOP at the time of sowing as basal dose and split application of urea at top dressing. The 6-10 days interval irrigations were applied during growing season. Intercultural operations viz., thinning, hoeing and weeding were followed after 20 days of sowing to maintain recommended spacing and weed control. Two hand weeding during growing period and harvest maturing in 50 to 55 days after sowing and observations on tagged plants were recorded

\section{Results and Discussion}

The data on growth and quality attributes parameters as well as soil fertility status after harvest the crop as influenced by combined application of nutrients, plant growth regulators and curing methods of the different treatments are presented in Table 1 and 2.

\section{Growth attributes}

\section{Effect of nutrients}

The tallest plants $(51.86 \mathrm{~cm})$ with highest number of leaves (11.28) and richest chlorophyll content in leaves $(0.69 \mathrm{mg} / \mathrm{g})$ were observed under NPKSB treatment. This nutrient combination was found significantly superior over rest of the combination of nutrients. However, it was statistically identical with NPKS treatment in case of plant height. Further, application of NPKSB exhibited earliest 50\% neck fall (113.74 days) followed by NPKS (114.93 days) and it was significantly earlier than that under NP and NPK. Application of nutrients in various combinations did not exert any significant effect on bolting percentage in onion crop (Table 1). The remarkable increase in plant growth due to combined application of $\mathrm{N}, \mathrm{P}$, $\mathrm{K}, \mathrm{S}$ and $\mathrm{B}$ might be the result of accelerated cell elongation and cell division. It is well known that nitrogen being an ingredient of chloroplast is the most indispensable mineral nutrient for growth and development of the plant. It might have helped in increased synthesis of photosynthates, which are further utilized in building up of new cell, leading to better vigour. Likewise phosphorus being essential constituent of cellular protein and nucleic acid might have encouraged meristemetic activity of plants resulting in increased plant height and number of leaves per plant. The added potassium might have resulted in increased synthesis and translocation of photosynthates, which were further utilized in building up of new cells leading to better vigour and more number of leaves per plant. Adequate supply of sulphur for vegetative growth might be also resulted into greater absorption of nitrogen from soil. Therefore, application of sulphur might have improved plant growth by meeting of higher nutritional demand of plants (Tripathy et al., 2013). The increment in vegetative growth of onion by the application of boron might be due to the fact that boron helps in growth of meristemetic tissues, cell division, and also increases the permeability of cell membrane and, thereby, facilitates the transport of sugars, which ultimately increased vegetative growth. These results are in consonance with the findings of Ballabh and Rana (2012) in onion crop.

\section{Effect of nutrient and plant growth regulators}

Application of ethephon @ 3000 ppm exhibited earliest duration (112.82 days) for $50 \%$ neck fall followed by mepiquat chloride @ 750 ppm (114.33 days) in onion and it was significantly earlier than $\mathrm{CaCl}_{2} @ 0.5 \%$ (119.63 days) and control (123.35 days). However, application of nutrients and plant growth regulators have non- significant effect on plant height, number of leaves per plant, chlorophyll content in leaves and bolting percentage in onion (Table 1). 
Table.1 Effect of nutrients and plant growth regulators on growth attributes in onion2016-17 \& 2017-18 (Pooled)

\begin{tabular}{|c|c|c|c|c|c|}
\hline Treatments & Plant height (cm) & $\begin{array}{c}\text { Number of leaves } \\
\text { per plant }\end{array}$ & $\begin{array}{l}\text { Chlorophyll content } \\
\text { in leaves }(\mathrm{mg} / \mathrm{g})\end{array}$ & $\begin{array}{c}\text { Days to } 50 \% \text { neck } \\
\text { fall }\end{array}$ & Bolting (\%) \\
\hline \multicolumn{6}{|l|}{ Nutrients } \\
\hline $\mathbf{N}_{1}$ & 44.17 & 8.23 & 0.40 & 122.60 & 0.24 \\
\hline $\mathbf{N}_{2}$ & 48.69 & 9.45 & 0.52 & 118.87 & 0.19 \\
\hline $\mathbf{N}_{3}$ & 50.74 & 10.30 & 0.60 & 114.93 & 0.23 \\
\hline $\mathbf{N}_{4}$ & 51.86 & 11.28 & 0.69 & 113.74 & 0.15 \\
\hline SEm \pm & 0.97 & 0.26 & 0.02 & 1.46 & 0.08 \\
\hline $\mathrm{CD}(\mathrm{P}=\mathbf{0 . 0 5})$ & 2.72 & 0.72 & 0.06 & 4.11 & NS \\
\hline \multicolumn{6}{|c|}{ Nutrients and plant growth regulators } \\
\hline$G_{1}$ & 47.79 & 9.13 & 0.52 & 123.35 & 0.25 \\
\hline $\mathbf{G}_{2}$ & 48.77 & 9.60 & 0.55 & 119.63 & 0.20 \\
\hline $\mathbf{G}_{3}$ & 49.18 & 10.15 & 0.57 & 112.82 & 0.22 \\
\hline $\mathbf{G}_{4}$ & 49.72 & 10.40 & 0.58 & 114.33 & 0.14 \\
\hline SEm \pm & 0.97 & 0.26 & 0.02 & 1.46 & 0.08 \\
\hline $\mathrm{CD}(\overline{\mathbf{P}}=\mathbf{0 . 0 5})$ & NS & NS & NS & 4.11 & NS \\
\hline
\end{tabular}


Table.2 Effect of nutrients, plant growth regulators and curing on quality attributes in onion 2016-17 \&2017-18 (Pooled)

\begin{tabular}{|c|c|c|c|c|}
\hline Treatments & TSS (\%) & SCB $(\%)$ & APDS(mg/g) & UBS (\%) \\
\hline \multicolumn{5}{|l|}{ Nutrients } \\
\hline $\mathbf{N}_{1}$ & 9.54 & 0.562 & 5.51 & 75.35 \\
\hline $\mathbf{N}_{2}$ & 10.16 & 0.661 & 6.49 & 78.31 \\
\hline $\mathbf{N}_{3}$ & 10.78 & 0.699 & 7.41 & 83.99 \\
\hline $\mathbf{N}_{4}$ & 10.86 & 0.748 & 8.50 & 85.10 \\
\hline SEm \pm & 0.05 & 0.009 & 0.06 & 0.35 \\
\hline $\mathrm{CD}(\mathrm{P}=\mathbf{0 . 0 5})$ & 0.15 & 0.026 & 0.17 & 0.99 \\
\hline \multicolumn{5}{|c|}{ Nutrients and plant growth regulators } \\
\hline $\mathbf{G}_{1}$ & 9.57 & 0.581 & 6.00 & 77.75 \\
\hline $\mathbf{G}_{2}$ & 10.18 & 0.648 & 6.58 & 78.72 \\
\hline $\mathbf{G}_{3}$ & 10.74 & 0.706 & 7.54 & 82.24 \\
\hline $\mathbf{G}_{4}$ & 10.84 & 0.735 & 7.79 & 84.03 \\
\hline SEm \pm & 0.05 & 0.009 & 0.06 & 0.35 \\
\hline $\mathrm{CD}(\mathrm{P}=\mathbf{0 . 0 5})$ & 0.15 & 0.026 & 0.17 & 0.99 \\
\hline \multicolumn{5}{|l|}{ Curing } \\
\hline $\mathrm{C}_{1}$ & 10.31 & 0.658 & 6.97 & 80.74 \\
\hline $\mathrm{C}_{2}$ & 10.24 & 0.668 & 6.94 & 80.73 \\
\hline $\mathbf{C}_{3}$ & 10.45 & 0.677 & 7.03 & 80.58 \\
\hline SEm \pm & 0.05 & 0.008 & 0.05 & 0.31 \\
\hline $\mathrm{CD}(\mathrm{P}=0.05)$ & 0.13 & NS & NS & NS \\
\hline
\end{tabular}

TSS= Total soluble solids, SCB= sulphur content in bulb, APDS= allyl propyl disulphide in bulbs, UBS= uniformity in bulb size 
Earliness due to application of ethephon might be imputed that ethephon is ethylenereleasing compound, can induce leaf senescence, which in leads to cell death (Chen et al., 2010). The onset and progression of plant growth and senescence can be influenced by exogenous and endogenous application of ethephon affecting the photosynthetic efficiency, the enzyme activities and nutritional value. Jana and Kabir (1991) reported that application of ethrel @ 300 ppm significantly increased plant height of cauliflower $c v$. Dania. However, growth had adversely affected at higher concentration. Earliness of the crop has been a claimed benefit from mepiquat chloride application.

\section{Quality attributes}

\section{Effect of nutrient}

The total soluble solids (10.86\%), sulphur content $(0.748 \%)$, allyl propyl disulphide content $(8.50 \mathrm{mg} / \mathrm{g})$ and uniformity in bulb size $(85.10 \%)$ exhibited maximum with the application of NPKSB and it was significantly superior over rest of the nutrient combinations (Table 2). However, this treatment was statistically identical with NPKS in respect to total soluble solid contents in bulbs. Total soluble solids content in bulbs increased with the application of nitrogen favoured photosynthetic activity of the plants so there was greater accumulation of food material i.e. carbohydrates in the bulb, which synthesized to saccharides and there was increase in total soluble solids content in bulbs. Increased availability of phosphorus owing its application might have increased the photosynthesis and carbohydrate synthesis resulting into greater accumulation of food material which ultimately increased the total soluble solids content in bulbs. Potassium is highly mobile within plant tissues and has a major role in plant metabolism as it activates the carbohydrates metabolism in plant system. The values of total soluble solids and sulphur content in onion bulbs were higher in association with potassium (Faten et al., 2010). Application of sulphur increased synthesis of primary flavour compounds with sulphur containing amino acids whose production increases with the increase in sulphur contents in onion as reported by Randle and Bussard (1993). Sulphur increased total soluble solids, sulphur contents and allypropyl disulphide in onion bulb (Kumar and Singh, 1992). Similarly, sulphur content and allyl propyl disulphide contents in bulb increased with application of NPK and $S$ might be due to the sulphur nutrient in soil solution with sulphur fertilization. The soil application of boron might have increased rate of photosynthesis leading to higher carbohydrate production resulting in enhancement of total soluble solids in onion bulb. As boron play very important role in the photosynthetic activities of plant and, thereby, facilitates the transport of sugars in plant system.

\section{Effect of nutrient and plant growth regulators}

The data (Table 2) pertaining to the quality attributes clearly indicates that total soluble solids $(10.84 \%)$, sulphur content $(0.735 \%)$, allyl propyl disulphide content $(7.79 \mathrm{mg} / \mathrm{g})$ in the bulb and uniformity of bulb size $(85.03 \%)$ were increased significantly with foliar application of mepiquat chloride @ 750 ppm and this treatment was found significantly superior over other treatments. However, it was statistically identical with ethephon@ $3000 \mathrm{ppm}$ in respect to total soluble solids in bulbs. The improvement in the quality attributes might be due to the treatment of anti-gibberellin compound like mepiquat chloride, which facilitate the translocation of photo-assimilates from source to sink thereby, enhancing bulb growth and enhancement of 
sink strength would be able to absorb the incoming sucrose more efficiently and converting into soluble forms as reported by Rees and Morrel, 1990 in potato. Al-Saif et al., (2017) reported that spray of ethephon @ $1500 \mathrm{ppm}$ at rutab stage gave the highest total soluble solids in date palm. The results obtained are also in close conformity with that of Zhao et al., (2009) in sorghum.

\section{Effect of curing}

The Bulbs cured under poly tunnel exhibited maximum total soluble solids $(10.45 \%)$ in the bulbs. It was significantly higher over other curing methods. Sulphur content, allyl propyl disulphide in bulbs and uniformity in bulb size was non-significantly differing with different curing methods (Table 2). The increase in total soluble solids might be because of conversion of polysaccharides into soluble forms of sugars. Wheeler et al., (1998) described that the difference for TSS was due to the movement of TSS from foliage to the bulbs until total fall over of the top and that bulb loss moisture by curing increase the concentration of soluble solids of the bulb. The results are in close agreement with the findings of Kaynas et al., (1995) and Nabi et al., (2013) in onion.

\section{References}

Al-Saif, A.M., Alebidi, A.I., Al-Obeed, R.S. and Soliman, S.S. 2017. Preharvest ethephon spray on fruit quality and increasing the rate of ripening of date palm fruit (Phoenix dactylifera L.) cv. Helali. Progress in Nutrition, 19(1): 97103.

Ballabh, K. and Rana, D.K. 2012. Response of micronutrients on qualitative and quantitative parameters of onion (Allium cepa L.). Progressive Horticulture, 44: 40-46.

Chen, H.J., Tsai, Y.J., Chen, W.S., Huang,
G.J., Huang, S.S. and Lin, Y.H. 2010.

Ethephon-mediated effects on leaf senescence are affected by reduced glutathione and EGTA in sweet potato detached leaves. Botanical Studies, 51: 171- 181.

Faten, S.A., Shaheen, A.M., Rizk, A.F. and Hafez, M.M. 2010. Influence of irrigation intervals and potassium fertilization on productivity and quality of onion plant. International Journal of Academic Research, 2: 110-116.

Jana B.K. and Kabir 1990. Effect of Sulphur on growth and yield of onion cv. Nasik red. Crop Research, 3: 241-243.

Kaynas, K., Besirli, G. and Damgaci, E. 1995. Using of bulk storage system on curing and storage potentials of onion bulbs. Central Horticultural Research Institute, Yalova (Turkey). pp: 32.

Kumar, A. and Singh, O. 1992. Dry matter accumulation in sulphur deficient onion plants. Indian Journal of Agricultural Research, 26(2): 107-109.

Marschner, P. 2012. Marschner's Mineral Nutrition of Higher Plants. Third Edition. Academic Press, Elsevier.

Nabi, G., Rabi, A., Sajidi, M., Abbas, F. S. J. and Ali, I. 2013. Influence of curing method and storage conditions on the post harvest quality of onion bulbs. Pakistan Journal of Botany, 45(2): 455460.Pettigrew, W.T. and Johnson, J.T. 2005. Effects of different rates and plant growth regulators on early planted cotton. Journal of Cotton Science, 9:189-198.

Rahman, A. M. and Isenberg, F.M.R. 1974. The role of exogenous plant regulators in the dormancy of onion bulbs. Journal of Agriculture Science, 82:113-116.

Randle, W.M. and Bussard, M.L. 1993. Pungency and sugars of short day onion as affected by sulphur nutrition. Journal of American Society of Horticultural Sciences, 118(6): 766-770. 
Rees, T. and Morrel, S. 1990. Carbohydrate metabolism in developing potatoes. American Journal of Potato, 67: 835847.

Tripathy, P., Sahoo, P.B.B., Das, A.S.K. and Dash, D.K. 2013. Effect of sources and levels of sulphur on growth, yield and bulb quality in onion (Allium cepa L.). International Journal of Bio-resource and Stress Management, 4(4): 641-644.

Wheeler, T.R., Daymond, A.J., Ellis, R.H., Morison, J.I.L. and Hadley, P. 1998. Postharvest sprouting of onion bulbs grown in different temperature and
Carbon dioxide environments in the UK. Journal Horticulture Science and Biotechnology, 73: 750-754.

Yawalker, K.S., Agrwal, J.P. and Bokde, S. 1962. Manures and fertilizer- AgriHorticultural Publishing House, Nagpur, 490010, India.

Zhao, Y.L., Dolat, A., Steinberger, Y., Wang, X., Osman, A. and Xie, G.H. 2009. Biomass yield and changes in chemical composition of sweet sorghum cultivars grown for biofuel field. Crop Research, 111(1\&x2): 55-64.

\section{How to cite this article:}

Priynka Kumari Jat, S.K. Khandelwal and Maharia, J.S. 2020. Performance of Nutrients and Plant Growth Regulators on Growth and Quality attributes of Onion (Allium cepa L.). Int.J.Curr.Microbiol.App.Sci. 9(10): 2977-2984. doi: https://doi.org/10.20546/ijcmas.2020.910.359 